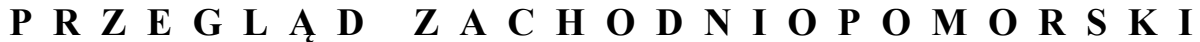 ROCZNIK XXXIII (LXII) ROK 2018 ZESZYT 3
}

\author{
ZYGMUNT KOZAK \\ Wydział Humanistyczny, Uniwersytet Szczeciński \\ e-mail: zygmunt.kozak@usz.edu.pl
}

\section{Przeobrażenia zabezpieczenia PoRtów lotniczych W KONTEKŚCIE ZAGROŻENIA TERRORYSTYCZNEGO}

Słowa kluczowe: lotnictwo, bezpieczeństwo, port lotniczy, terroryzm

Keywords: flight, security, airport, terrorism

\section{Wprowadzenie}

Bezpieczeństwo w lotnictwie powinno stanowić fundament wykonywania wszelkich operacji w przestrzeni powietrznej. Decyduje o życiu wielu ludzi i angażuje ogromne środki materialne ${ }^{1}$. Obejmuje nie tylko to, co dzieje się w powietrzu, czyli bezpieczne wykonywanie lotów, ale przede wszystkim to, co dzieje się na ziemi, począwszy od infrastruktury portu lotniczego ${ }^{2}$, a skończywszy na jego ochronie. Każdy port lotniczy jest obiektem, który w sposób szczególny

${ }^{1}$ A. Kwasiborska, Przedmowa, w: Bezpieczeństwo transportu lotniczego. Wybrane aspekty, red. A. Kwasiborska, Pułtusk-Warszawa 2016, s. 7; P. Czech, Źródło i ksztalt polityki bezpieczeństwa Unii Europejskiej kreowanej względem transportu lotniczego, w: Bezpieczeństwo transportu lotniczego..., s. 11, 13.

${ }^{2}$ Infrastruktura lotniska (portu lotniczego) obejmuje: część lotniczą lotniska (jest to pole wzlotów, pole manewrowe, płyty postojowe statków powietrznych), lotnicze urządzenia naziemne (należą do nich: urządzenia radiokomunikacyjne, radiolokacyjne, radionawigacyjne, automatyczne systemy pomiarowe parametrów meteorologicznych), urządzenia i obiekty przeznaczone do obsługi naziemnej (są to przede wszystkim terminale pasażerskie i cargo, magazyny paliw i materiałów pędnych oraz hangary, w których naprawia się i obsługuje technicznie statki powietrzne) - J. Duszewski, Wybrane aspekty funkcjonowania portów lotniczych i obslugi pasażerów, 
narażony jest na akty terrorystyczne, uprowadzenia osób, pojazdów bądź samolotów³. Uwzględniając infrastrukturę portu lotniczego, zjawisk takich może być znacznie więcej. Zachowanie odpowiedniego poziomu bezpieczeństwa przez linie lotnicze jest istotnym warunkiem ich rozwoju.

Celem artykułu jest omówienie rozwoju terroryzmu lotniczego na świecie w XX i XXI wieku oraz metod i środków ochrony portów lotniczych przed zagrożeniami terrorystycznymi.

\section{Historia i ewolucja terroryzmu lotniczego}

Zagadnienie terroryzmu lotniczego w lotnictwie cywilnym pojawiło się pod koniec pierwszej połowy XX wieku wraz z rozwojem lotnictwa komunikacyjnego - pasażerskiego. Przyjęto, że terroryzm lotniczy to akt terroru skierowany przeciwko lotnictwu, przeprowadzony zarówno w powietrzu, jak i na ziemi przeciwko całej infrastrukturze związanej z lotnictwem ${ }^{4}$.

Powszechnie uważa się, że pierwszym przypadkiem terroryzmu lotniczego było porwanie przez peruwiańskich rewolucjonistów 21 lutego 1931 roku w miejscowości Arequipa (Peru) samolotu Ford Trimotor ${ }^{5}$. Porywacze zażądali od pilota rozrzucenia ulotek propagandowych ${ }^{6}$. W latach czterdziestych ubiegłego wieku uprowadzenia samolotów były zjawiskiem rzadkim. Pierwszym przypadkiem w tym czasie - według Międzynarodowej Organizacji Lotnictwa Cywilnego (ICAO - International Civil Aviation Organization) - było porwanie w 1948 roku samolotu lecącego z Macao7. Inne źródła podają rok 1947, kiedy to uprowadzono

w: Bezpieczeństwo transportu lotniczego..., s. 37, 38; D.G. Czyżewski, Procedury ochrony w lotnictwie, w: Bezpieczeństwo transportu lotniczego..., s. 56-58.

${ }^{3}$ A. Glen, Terroryzm lotniczy. Istota zjawiska, organizacja przeciwdziałania, Warszawa 2014, s. 14.

${ }^{4}$ Leksykon Bezpieczeństwa Wewnętrznego, red. W. Fehler, J. Piątek, R. Podgórzańska, Szczecin 2017, s. 638; J. Laskowski, Terroryzm lotniczy - charakterystyka zjawiska, „Studia Historyczno-Społeczne" 2013, nr 7, s. 133.

${ }^{5}$ G. Zając, Prawne i organizacyjne rozwiązania w zakresie bezpieczeństwa w lotnictwie cywilnym, w: Zarzadzanie bezpieczeństwem lotnictwa cywilnego, red. J. Szczucki, M. Gąsior, G. Zając, M. Szczelina, Wrocław [b.d.w.], s. 147.

${ }^{6}$ B.I. Koerner w pracy Niebo jest nasze. Miłość i terror w złotym wieku piractwa powietrznego (Wołowiec 2017) pisze, że historia pierwszego porwania samolotu jest zmyślona. Źródeł jej należy szukać w artykule opublikowanym w październiku 1961 r. w „Family Weekly”, a napisanym przez rzekomą ofiarę tego porwania, Byrona D. Richardsona.

${ }^{7}$ K. Jałoszyński, Wspótczesne zagrożenie terroryzmem powietrznym. Kierunki przedsięwzięć w zakresie przeciwdziałania mu oraz walki z tym zjawiskiem, w: Bezpieczne niebo, materiały pokonferencyjne, red. A. Doraczyńska, D. Strasburger, Warszawa 2002, s. 117. 
samolot rumuńskich linii lotniczych ${ }^{8}$. W tym też okresie (1948 r.) doszło do pierwszego uprowadzenia samolotu Polskich Linii Lotniczych LOT.

W latach sześćdziesiątych ubiegłego wieku uprowadzenie samolotu stało się zjawiskiem o zasięgu światowym ${ }^{9}$. Najwięcej porywano samolotów linii lotniczych Kuby, Kolumbii i Stanów Zjednoczonych ${ }^{10}$. Kilkadziesiąt incydentów odnotowano $\mathrm{w}$ innych częściach świata, a porywaczami byli głównie uciekinierzy z bloku państw komunistycznych.

22 lipca 1968 roku trzech terrorystów Ludowego Frontu Wyzwolenia Palestyny uprowadziło lecący z Rzymu do Tel Awiwu rejsowy samolot Boeing 707 izraelskich linii lotniczych $\mathrm{El} \mathrm{Al}{ }^{11}$. Jak wspomniano, uprowadzenie samolotu w tym okresie nie było nowością, niespotykane natomiast były żądania i motywy terrorystów ${ }^{12}$. Po raz pierwszy uprowadzenie samolotu wraz z pasażerami stanowiło kartę przetargową ugrupowań palestyńskich - żądali oni uwolnienia osadzonych w więzieniach bojowników Organizacji Wyzwolenia Palestyny.

${ }^{8}$ B. Hołyst, Terroryzm, Warszawa 2011, s. 998.

${ }^{9}$ B. Heide, Zabezpieczenie lotów i portów lotniczych na wypadek ataków terrorystycznych, http://docplayer.pl/4658072-zabezpieczenie-lotow-i-portow-na-wypadek-atakow-terrorystycznych.html (dostęp: 20.02.2018).

10 W latach 1961-1972 w amerykańskiej przestrzeni powietrznej porwano 159 samolotów pasażerskich. Eksperci i politycy określali fale tych porwań mianem „epidemii”. Był to okres, kiedy linie lotnicze zaczęły upowszechniać podróżowanie samolotem. Nie przeprowadzano żadnych kontroli, pasażer, nie pokazując ani biletu, ani dowodu tożsamości, mógł przejść przez cały budynek lotniska, pas startowy i wnieść swój bagaż na pokład samolotu. Zdarzały się przypadki, że za przelot płacono dopiero w powietrzu. Linie lotnicze obawiały się, że kontrole sprawią, iż pasażerowie będą czuli się mało komfortowo i wybiorą inny środek transportu. Wygoda pasażerów była ważniejsza niż bezpieczeństwo, a opłacanie okupów za uprowadzenie 30-40 samolotów rocznie poszczególnych linii komunikacyjnych generowało mniejsze koszty niż wdrożenie stałej ochrony na lotnisku. W omawianym okresie porwanie samolotu nie było przestępstwem, sprawców sądzono za przestępstwo związane z użyciem lub groźbą użycia broni. Przełomowym wydarzeniem było uprowadzenie w listopadzie 1972 r. samolotu Western Airlines lot 49, lecącego nad środkową Alabamą. Porywacze zagrozili, że jeżeli nie otrzymają okupu, rozbiją samolot o reaktor jądrowy w Knoxvill. Sytuacja ta doprowadziła do tego, że Federalna Agencja Lotnictwa USA i linie lotnicze wprowadziły stałe kontrole bezpieczeństwa - B.J. Koerner, Niebo jest nasze..., s. $18-21,218-221$.

${ }^{11} \mathrm{~J}$. Laskowski pisze, że uprowadzenie samolotu izraelskich linii lotniczych El Al, które miało miejsce w lipcu, było jedyne do tej pory. Osiągnięcie takiego poziomu bezpieczeństwa było możliwe dzięki wnikliwej analizie tego zdarzenia, w wyniku czego wprowadzono intensywne przesłuchania pasażerów przed wejściem na pokład samolotu, fizyczne przeszukania osób i statków powietrznych oraz uzbrojonych strażników na pokładzie każdego samolotu - J. Laskowski, Terroryzm lotniczy..., s. 147.

$12 \mathrm{~B}$. Węgliński, Wybrane aspekty ewolucji systemu bezpieczeństwa lotnictwa cywilnego w latach 1968-2009, „Rocznik Bezpieczeństwa Międzynarodowego” 2009/2010, s. 205. 
„Czarnym dniem” bądź „Niedzielą porwań” światowych przewoźników powietrznych okazał się 6 września 1970 roku, kiedy w ciągu godziny członkowie Ludowego Frontu Wyzwolenia Palestyny uprowadzili jednocześnie cztery samoloty ${ }^{13}$ lecące do Nowego Jorku. Zakładników uwolniono, kiedy rządy Wielkiej Brytanii, Szwajcarii i Republiki Federalnej Niemiec podjęły decyzję o zwolnieniu z więzień palestyńskich terrorystów. Ustępstwa te nie spowodowały jednak zwrotu samolotów, które zostały zniszczone.

Początek lat siedemdziesiątych XX wieku, oprócz uprowadzeń samolotów, zapoczątkował zupełnie nową, niezwykle niebezpieczną dla lotnictwa cywilnego taktykę działania terrorystów - atakowanie samolotów za pomocą przenośnych przeciwlotniczych zestawów rakietowych ${ }^{14}$.

Dotychczas koncepcja wykorzystania samolotów pasażerskich w działaniach terrorystycznych sprowadzała się do ich porwania wraz z pasażerami, a następnie prowadzenia negocjacji z władzami. Pierwsze zdarzenie świadczące o zmianie podejścia terrorystów do kwestii wykorzystania samolotów pasażerskich miało miejsce 24 grudnia 1994 roku, gdy terroryści należący do Algierskiej Zbrojnej Grupy Islamskiej porwali francuski samolot linii lotniczych Air France (Airbus A300) lecący do Algieru' ${ }^{15}$ i wylądowali w Marsylii. Dwa dni później żandarmi z jednostki antyterrorystycznej GING (Groupe d'Intervention de la Gendarmerie Nationale Grupa Interwencyjna Żandarmerii Wojskowej) przeprowadzili szturm, w wyniku którego śmierć ponieśli wszyscy terroryści, a kilku pasażerów i żandarmów zostało rannych. Na podstawie przeprowadzonego śledztwa ustalono, że terroryści zamierzali rozbić samolot na wieży Eiffla w Paryżu ${ }^{16}$.

Tragiczne wydarzenia z 11 września 2001 roku na terenie Stanów Zjednoczonych były apogeum terroryzmu lotniczego. Terroryści dopuścili się bezprecedensowego w dziejach lotnictwa aktu przemocy. Było to skoordynowane porwanie czterech odrzutowych samolotów pasażerskich, startujących z lotnisk na wschodnim wybrzeżu Stanów Zjednoczonych ${ }^{17}$. Wszystkie maszyny zostały rozbite w wyniku

${ }^{13}$ J. Gotowała, Niepokój w powietrzu - wydajność wspótczesnych systemów zapobiegających szczególnym sytuacjom w locie, w: Bezpieczne niebo..., s. 14; J. Laskowski, Terroryzm lotniczy..., s. 147, 148.

14 J. Laskowski, Terroryzm lotniczy..., s. 151; A. Glen, Terroryzm lotniczy..., s. 22, 23.

15 J. Adamski, Nowe technologie w stużbie terrorystów, Warszawa 2007, s. 53.

${ }^{16}$ K. Jałoszyński, Współczesne zagrożenia terroryzmem..., s. 123; Encyklopedia terroryzmu, Warszawa 2004, s. 697; B. Hołyst, Terroryzm, s. 473, 2114; J. Laskowski, Terroryzm lotniczy..., s. 154.

17 Literatura poświęcona zamachowi z 11 września 2001 r. jest bardzo obszerna, zobacz m.in. Bezpieczne niebo...; Z. Jagodzińska, Pierwsza odstona wojny z terroryzmem islamskim. 
aktu terroryzmu powietrznego, który swoim okrucieństwem przewyższył wszystkie dotychczasowe zamachy. Po tych wydarzeniach doszło do kilku zdarzeń eksponujących możliwości wykorzystania samolotów pasażerskich w charakterze narzędzia terroru, trafiającego w obiekty publiczne wybrane przez terrorystów.

5 stycznia 2002 roku 15-letni kursant szkoły latania porwał i rozbił samolot (Cessna) o wieżowiec w Tampie na Florydzie. Pilot zginął, w niewielkim stopniu uszkadzając konstrukcję budynku.

Rok później obywatel Niemiec porwał motoszybowiec z niemieckiego lotniska Babenhausen pod Frankfurtem nad Menem. Po sterroryzowaniu pilota i przejęciu sterów, latając nad centrum miasta, zagroził, że roztrzaska się o gmach Europejskiego Banku Centralnego. Ostatecznie, po dwóch godzinach, wylądował na frankfurckim lotnisku ${ }^{18}$.

Na przełomie listopada i grudnia 2002 roku Al Kaida planowała zaatakować ambasadę USA w Nairobi. Zamachowcy (dwóch Arabów przybyłych z Somalii), wykorzystując mały samolot pasażerski wypełniony materiałem wybuchowym, zamierzali uderzyć w budynek ambasady. Zamknięcie jej 28 listopada udaremniło te plany. Pod koniec roku amerykańskie służby specjalne uniemożliwiły zamach w Los Angeles, który planowano zrealizować według scenariusza z 11 września. Obiektem zamachu miał być drapacz chmur Library Tower. W styczniu 2004 roku, po informacji uzyskanej przez CIA, odwołano rejs samolotu linii British Airways z Londynu do Waszyngtonu. W listopadzie tego roku służby brytyjskie udaremniły również przeprowadzenie przez Al-Kaidę zamachów z użyciem samolotów pasażerskich na lotnisko Heathrow w Londynie na centrum finansowe Canary Wharf ${ }^{19}$.

Organizacje terrorystyczne na przestrzeni lat zastosowały wiele różnorodnych form i metod terroru lotniczego ${ }^{20}$. W początkowym okresie było to uprowadzenie samolotów z pasażerami jako zakładnikami. W okresie późniejszym niszczono statki powietrzne bądź przekazywano ultimatum z pokładu uprowadzonego samolotu do konkretnego kraju lub wielu państw jednocześnie ${ }^{21}$.

Nowy Jork i Waszyngton - 11 września 2001, w: Miasta trwogi..., s. 10-107; S. Kozak, Operacja Dwie Wieże..., s. 33.

18 J. Adamski, Nowe technologie..., s. 53.

19 Tamże, s. 54, 55

${ }^{20}$ A. Glen, Terroryzm lotniczy..., s. 48.

21 J. Gotowała, Niepokój w powietrzu - nowe oblicze terroryzmu, w: Terroryzm - globalne wyzwanie, red. K. Kowalczyk, W. Wróblewski, Toruń 2006, s. 117. 


\section{Bezpieczeństwo portów lotniczych}

Terroryzm lotniczy na przestrzeni lat przeszedł ewolucję - od porwań samolotów w celu emigracji o podłożu politycznym (uzyskanie azylu w innym państwie), przez porwania dla osiągnięcia szantażem konkretnych celów ekonomicznych, a skończywszy na wykorzystaniu samolotów z pasażerami jako pocisku trafiającego w obiekty publiczne wybrane przez terrorystów.

Dla ochrony przed atakami terrorystycznymi lotnictwo cywilne musiało poszukiwać sposobów zapewniających maksymalny stopień ochrony, uwzględniając jednocześnie komfort podróżowania, bez nadmiernej uciążliwości odpraw i procedur bezpieczeństwa.

Kiedy w latach siedemdziesiątych ubiegłego wieku uprowadzenia samolotów miały charakter „ucieczkowy”, wprowadzono kontrolę bagażu kabinowego i osób celem wykrycia broni bądź przedmiotów mogących posłużyć terroryście do zastraszenia załogi.

Jak ważnym aspektem było zachowanie bezpieczeństwa w porcie lotniczym, pokazał zamach terrorystyczny przeprowadzony 21 grudnia 1988 roku na samolot pasażerski linii Pan American World Airways nad Lockerbie w Szkocji ${ }^{22}$. Na pokładzie Boeinga 747 (lot 103), lecącego z Londynu do Nowego Jorku, eksplodowała bomba z zapalnikiem czasowym, ukryta $\mathrm{w}$ magnetofonie Toshiba $\mathrm{w}$ jednej z walizek w luku bagażowym. Zginęło wówczas 243 pasażerów, 16 członków załogi, a spadające szczątki samolotu spowodowały śmierć 11 mieszkańców miasta. Ofiary zamachu pochodziły z 21 krajów. Zamachowcy w swoich planach nie uwzględnili 25-minutowego opóźnienia samolotu, sądzili, że bomba eksploduje nad oceanem, co uniemożliwiłoby stwierdzenie przyczyn katastrofy. Pośrednim skutkiem tego zamachu był upadek istniejącej od 1927 roku linii Pan American World Airways, na którą Federalny Zarząd Lotnictwa USA nałożył karę ponad pół miliarda dolarów za braki w systemie bezpieczeństwa na lotnisku we Frankfurcie. Natomiast liczne sprawy sądowe, które przewoźnikowi wytoczyły rodziny ofiar katastrofy, doprowadziły firmę do bankructwa. Po tym zdarzeniu podjęto wszechstronne działania mające na celu uchronienie pasażerów samolotów przed kolejnymi tego typu atakami. Decyzje rządu brytyjskiego doprowadziły do obowiązkowego screeningu bagażu głównego (kontrola bezpieczeństwa bagażu rejestrowanego)

22 J. Vankin, J. Whalen, Niewyjaśnione spiski naszych czasów, Warszawa 2017, s. 187 i n.; Cień Lockerbie, „Forum” 2009, nr 35, s. 10 i n.; R. Quest, Zaginiony lot MH 370. Prawdziwa historia poszukiwań malezyjskiego samolotu, Warszawa 2017, s. 96. 
dla rejsów atlantyckich. Pierwsze doświadczenia były zniechęcające ze względów operacyjnych, np. czas odprawy przed terminalem 1 na lotnisku Heathrow wydłużył się do czterech godzin, a kolejki osiągały długość $300 \mathrm{~m}$.

Rozpoczęto badania nad rozwiązaniami zapewniającymi wysokie parametry detekcyjne i dużą wydajność, nieblokującymi jednocześnie kontroli. Te sprzeczne wymagania zrealizowano za pomocą nowych urządzeń rentgenowskich. Systemy detekcji materiałów wybuchowych (EDS - Explosive Detection System) oraz systemy detekcji urządzeń wybuchowych (EDDS - Explosive Device Detection System) stały się powszechne w każdym porcie lotniczym. Pozwalają one (wykorzystując obraz rentgenowski) wykrywać i wskazywać w bagażu obszary, w których może znajdować się materiał wybuchowy bądź urządzenie wybuchowe ${ }^{23}$.

Wielka Brytania była pierwszym państwem na świecie, które rozwiązało problem screeningu bagażu głównego. Kosztem 285 mln funtów szterlingów zbudowano pięciopoziomowe ${ }^{24}$ systemy screeningowe na wszystkich brytyjskich lotniskach międzynarodowych.

W portach lotniczych do kontroli bezpieczeństwa pasażerów, oprócz konwencjonalnych urządzeń rentgenowskich, bramek do wykrywania metali (WTMD Walk Through Metal Detoctor) i ręcznych wykrywaczy metali (HHMD - Hand Held Metal Detector), zaczęto wprowadzać urządzenia do wykrywania śladowych ilości materiałów wybuchowych - bramki łączące detekcję metali z detekcją śladową materiałów wybuchowych (WTMD/TD - Walk Through Metal Detector/Trace Detector) ${ }^{25}$. Należy nadmienić, że w portach lotniczych montowane są urządzenia do automatycznego wykrywania materiałów wybuchowych podczas kontroli bagażu, np. Mi-Scan 10050 EDS, które opracowano zgodnie

${ }^{23}$ M. Dilling, Bezpieczeństwo w portach lotniczych, w: Bezpieczne niebo..., s. 89.

${ }^{24}$ Poziom I - urządzenia EDS/EDDS pracują w trybie automatycznym. Średnio 70\% bagaży jako bagaże bezpieczne kierowanych jest na pokład samolotu; poziom II - obrazy rentgenowskie, $30 \%$ bagaży przekazywanych jest na stacje monitorowania. Na obrazie zaznaczony jest obszar wymagający decyzji operatora. Czas decyzji operatora jest ograniczony do ok. 10-20 sek. Jeśli decyzja pozytywna nie nastąpi w tym czasie, bagaż kierowany jest na poziom III. Poziom III - są to urządzenia EDS/EDDS za stacją roboczą i operatorem bądź urządzenia wysokiej rozdzielczości (tomografy, urządzenia dyfrakcyjne); czas decyzji operatora (nie jest ograniczony) średnio wynosi $45 \mathrm{~s}$. Przy braku pozytywnej decyzji bagaż przechodzi na poziom IV. Poziom IV - kontrola reczna bagażu w obecności pasażera. Poziom V - neutralizacja urządzenia wybuchowego na dowolnym etapie kontroli; jeżeli istnieje uzasadnione podejrzenie materiału wybuchowego (bomby) w bagażu, jest on kierowany pod kontrolę grupy pirotechników. Tamże, s. 90.

${ }_{25}$ Tamże, s. 91; A.A. Bagińska, Zapewnienie bezpieczeństwa w porcie lotniczym, Łódź-Lublinek, w: Bezpieczeństwo transportu lotniczego..., s. 103. 
z wytycznymi Europejskiej Konferencji Lotnictwa Cywilnego (European Civil Aviation Conference - ECAC). Zaprezentowano je po raz pierwszy jesienią 1995 roku na międzynarodowych targach technicznych wyposażenia lotnisk Inter Airport. Wykorzystując rozdzielczość widm rentgenowskich, urządzenie może prześwietlić 1200 sztuk bagażu w ciągu godziny ${ }^{26}$.

Po tragicznych wydarzeniach z 11 września 2001 roku wprowadzono ostre reżimy bezpieczeństwa w portach lotniczych na całym świecie. Dokonano weryfikacji krajowych strategii bezpieczeństwa oraz wprowadzono mechanizmy przeciwdziałające podobnym sytuacjom w przyszłości. Bezwzględnie zakazano wnoszenia na pokład samolotu ostrych przedmiotów ${ }^{27}$. Wprowadzono ściśle uregulowane zasady przewozu płynów i żeli. Kontrola osobista i bagażu stała się dokładniejsza i bardziej szczegółowa.

W portach lotniczych zaczęto wprowadzać nowoczesne rozwiązania technologiczne. W celu weryfikacji tożsamości pasażerów stosuje się metody biometryczne: identyfikację linii papilarnych, obrazu rogówki, kształtu dłoni, rysów twarzy. Przykładem zastosowania metod biometrycznych jest amerykański system US-VISIT (United States Visitor and Immigrant Status Indicator Technology), który analizuje zgromadzone dane biometryczne osób przybywających do Stanów Zjednoczonych ${ }^{28}$.

Począwszy od 2007 roku, Departament Bezpieczeństwa Krajowego (DHS - Departament of Homeland Security) wykorzystuje czytniki linii papilarnych wszystkich dziesięciu palców dłoni na głównych amerykańskich lotniskach. W 2010 roku lata później wdrożono trójwymiarowe skanery ciała, które są bardziej skuteczne w wykrywaniu metalu niż bramki ${ }^{29}$.

Podstawowym celem bezpieczeństwa portów lotniczych po zamachach we wrześniu 2001 roku było uniemożliwienie terrorystom dostania się na pokład samolotu. Pomimo objęcia portów lotniczych specjalną ochroną są one wciąż niebezpiecznymi obszarami ${ }^{30}$.

${ }^{26}$ B. Hołyst, Terroryzm..., s. 1268.

${ }^{27}$ W okresie poprzedzającym wrześniową tragedię w Stanach Zjednoczonych obowiązywały liberalne przepisy, np. można było wnieść nóż o ponad 10-centymetrowym ostrzu. Zamachowcy (Mohammed Atta i Abdulaziz al-Omari) bez problemu przeszli kontrolę bezpieczeństwa. Zdjęcia rentgenowskie ich toreb podróżnych nie zwróciły uwagi ochrony - A. Kaniewski, Piętnaście miesięcy do ,godziny zero”, „Fokus Extra” 2005, nr 1, s. 8.

${ }^{28}$ A.A. Bagińska, Zapewnienie bezpieczeństwa..., s. 106.

${ }^{29}$ G. Zając, Prawne i organizacyjne rozwiazania..., s. 150.

${ }^{30}$ W latach 2011-2016 przeprowadzono dziesięć zamachów lub prób zamachów w obrębie portów lotniczych. Były to m.in.: samobójczy atak bombowy na międzynarodowym lotnisku 
Najbardziej spektakularnym atakiem terrorystycznym w Europie w ostatnim czasie był zamach na brukselskim lotnisku w Zavenlem. 22 marca 2016 roku w godzinach rannych (około 8.00) w hali odlotów doszło do dwóch eksplozji31. Pierwsza miała miejsce między odprawami linii lotniczych British Airways oraz Iberia. Kilka sekund później, między lokalem Starbucks a odprawą przed odlotem samolotu Brussels Airlines, nastąpiła druga eksplozja.

Zamachowcy-samobójcy, którzy przeprowadzili atak na lotnisku, to Belgowie: bracia Khalid i Brahm El-Bakraoni ${ }^{32}$. Materiał wybuchowy wzmocniony elementami metalowymi (gwoździe, śruby) wnieśli w walizkach. Oba wybuchy zostały zainicjowane przed odprawą, a więc w miejscach, gdzie swobodnie poruszali się pasażerowie. W zamachu tym zginęło 17 osób.

Kilkanaście dni po marcowym zamachu na brukselskim lotnisku Zavenlem, w którym zginęło 17 osób, podjęto dyskusję, czy w europejskich portach lotniczych strefy bezpieczeństwa nie należy przesunąć do wejść do terminali. Po samobójczym zamachu bombowym (24.01.2014) w hali przylotów na międzynarodowym lotnisku Domodiedowo pod Moskwą kontrole wprowadzono także w niektórych portach lotniczych Rosji33. Rozwiązania takie są z kolei powszechne na wielu lotniskach w Azji Południowo-Wschodniej ${ }^{34}$.

Philip Baum, redaktor czasopisma „Aviation Security International Magazine”, kierujący jednocześnie firmą Green Light, która zajmuje się doradztwem w dziedzinie bezpieczeństwa komunikacji lotniczej, stwierdził, że „dodatkowe

w Kabulu, wybuch przed wyjściem z terminala na lotnisku w Pekinie, eksplozja materiału wybuchowego na pokładzie rosyjskiego samolotu lecącego z Szarm-el-Szejk; poza tym na terenie międzynarodowego lotniska w Kairze rozbrojono dwa ładunki wybuchowe - Terroryzm ponowoczesny jako zagrożenie dla lotnictwa cywilnego, http://bezpieczeństwo lotnisk.pl/index/php/ artykuły/59-terroryzm-ponowoczesny-jako-za (dostęp: 5.01.2018).

${ }^{31}$ Niedługo później doszło do wybuchu na stacji metra Maalbeek, Twierdza Europy, „Forum” 2016, nr 7, s. 16; J. Winiecki, Ł. Wójcik, Spokojnie, to tylko zamach, „Polityka” 2016, nr 14, s. 12.

32 A. Czarnota-Hooglugt, Atak grupy terrorystycznej ISIS. Wzrost zagrożenia $w$ Europie. Bruksela - 22 marca 2016, w: Miasta trwogi..., s. 215; M. Orzechowski, Mój brat terrorysta, „Polityka” 2016, nr 32, s. 54, 55.

$33 \mathrm{~W}$ zamachu zginęło 35 osób, a 180 zostało rannych. Wykorzystano $5 \mathrm{~kg}$ trotylu, który wzmocniono elementami metalowymi - K. Jałoszyński, S. Kulczyński, A. Kańciak, D. Szlachter, Działalność organizacji terrorystycznych, w: Współczesne zagrożenia terroryzmem, red. K. Jałoszyński, Szczytno 2013, s. 166.

${ }^{34}$ Strefy bezpieczeństwa (kontrole) wejść do terminali znajdują się m.in. w portach lotniczych: Suvarnabhumi (Bangkok), Soekarno-Hatta (Dżakarta), Ngurah Rai International Airport (Denpasar), Husein-Sastranegara (Bandung), Kuala Lumpur International Airport (KUL), Changi (Singapur) - przypis autora. 
stanowisko kontrolne pasażerów i bagażu przed wejściem do terminalu oznaczałoby dodatkowe kolejki, które potencjalnie mogłyby stać się celem terrorystów" ${ }^{35}$. Jednocześnie zwrócił uwagę, że „zamachowcy samobójcy często detonują ładunki wybuchowe właśnie na punktach kontroli bezpieczeństwa, gdzie zwykle w kolejkach stoi wielu ludzi"36.

Norman Shanks - były szef bezpieczeństwa lotniska Heathrow - w wywiadzie dla „New York Timesa” powiedział, że „są kraje, w których ludzie muszą okazać paszport i bilet przed wejściem do portu lotniczego. Ma to zapobiec wejściu tych, którzy nie są pasażerami, ale nie zapobiegnie to wejściu zamachowców, bo oni zawsze mogą kupić bilet" ${ }^{37}$. Koncepcję takich kontroli odrzuciła także brytyjska minister spraw wewnętrznych Theresa May, mówiąc w parlamencie, że „byłoby to po prostu tworzenie tłumu w innym miejscu”38.

Zamach w Brukseli potwierdził, że obecnego zagrożenia terrorystycznego nie zatrzymają żadne osiągnięcia techniki, ale muszą być podjęte radykalne działania wszelkich służb w obszarze wymiany informacji oraz wszechstronna współpraca.

\section{Podsumowanie}

Przedstawione w artykule zagadnienia, dotyczące bezpieczeństwa i ochrony portów lotniczych, są niezwykle istotne. Bez ciągłego modernizowania, udoskonalania oraz wprowadzania nowoczesnych rozwiązań technicznych szanse skutecznej walki z terroryzmem będą minimalne. Wydarzenia z 11 września 2001 sprawiły, że zmieniło się podejście do zagadnień dotyczących ochrony portów lotniczych. Autor ma świadomość, że ze względu na szerokie pojęcie bezpieczeństwa transportu lotniczego niektóre zagadnienia zostały jedynie zasygnalizowane. Wynika to z faktu, że problematyka dotycząca ochrony portów lotniczych nie jest dostępna opinii publicznej.

35 Cyt. za: Bezpieczeństwo na lotniskach. Zabezpieczenia antyterrorystyczne, https:// www.tvn24.pl/wiadomosci-ze-swiata,2/bezpieczenstwo-na-lotniskach-zabezpieczenia-antyterrorystyczne,657061.html (dostęp: 5.01.2018).

\footnotetext{
36 Tamże.

37 Tamże.

38 Tamże.
} 


\section{Bibliografia}

Adamski J., Nowe technologie w stużbie terrorystów, Warszawa 2007.

Bezpieczeństwo na lotniskach. Zabezpieczenia antyterrorystyczne, https://www.tvn24. $\mathrm{pl} /$ wiadomosci-ze-swiata,2/bezpieczenstwo-na-lotniskach-zabezpieczenie (dostęp: 5.01.2018).

Bezpieczeństwo transportu lot niczego. Wybrane aspekty, red. A. Kwasiborska, PułtuskWarszawa 2016.

Bezpieczne niebo, materiały pokonferencyjne, red. A. Doraczyńska, D. Strasburger, Warszawa 2002.

Borucki M., Terroryzm zło naszych czasów, Warszawa 2002.

Cień Lockerbie, „Forum” 2009, nr 35.

Encyklopedia terroryzmu, Warszawa 2004.

Glen A., Terroryzm lotniczy. Istota zjawiska, organizacja przeciwdziałania, Warszawa 2014.

Heide B., Zabezpieczenie lotów i portów lotniczych na wypadek ataków terrorystycznych, http://docplayer.pl/4658072-zabezpieczenie-lotów-i-portow-na-wypadek-atakow-terrorystycznych.html, (dostęp: 20.02.2018).

Hołyst B., Terroryzm, Warszawa 2011.

Kaniewski A., Piętnaście miesięcy do „,godziny zero”, „Focus Ekstra” 2005, nr 1.

Koerner B.I., Niebo jest nasze. Miłość i terror $w$ złotym wieku piractwa powietrznego, Wołowiec 2017.

Kozak S., Operacja dwie wieże, Warszawa 2007.

Laskowski J., Terroryzm lotniczy - charakterystyka zjawiska, „Studia Historyczno-Społeczne", Lublin 2013, nr 7.

Leksykon Bezpieczeństwa Wewnętrznego, red. W. Fehler, J. Piątek, R. Podgórzańska, Szczecin 2017.

Miasta trwogi. Terroryzm na obszarze zurbanizowanym, red. A. Aksamitowski, M. Cupryjak, Z. Kozak, Szczecin 2016.

Orzechowski M., Mój brat terrorysta, „Polityka” 2016, nr 32.

Quest R., Zaginiony lot MH370. Prawdziwa historia poszukiwań malezyjskiego samolo$t u$, Warszawa 2017.

Terroryzm - globalne wyzwanie, red. K. Kowalczyk, W. Wróblewski, Toruń 2006.

Terroryzm ponowoczesny jako zagrożenie dla lotnictwa cywilnego, http://bezpiecznelotnisko.pl/index.php/artykuly/59-terroryzm-ponowoczesny-jako-zagrozenie (dostęp: 5.01.2018).

Twierdza Europy, „Forum” 2016, nr 7.

Vankin J., Wahlen J., Niewyjaśnione spiski naszych czasów, Warszawa 2017.

Węgliński B., Wybrane aspekty ewolucji systemu bezpieczeństwa lotnictwa cywilnego w latach 1968-2009, „Rocznik Bezpieczeństwa Międzynarodowego” 2009/2010. 
Winiecki J., Wójcik Ł., Spokojnie, to tylko zamach, „Polityka” 2016, nr 14.

Współczesne zagrożenia terroryzmem, red. K. Jałoszyński, Szczytno 2013.

Zarządzanie bezpieczeństwem lotnictwa cywilnego, red. J. Szczucki, M. Gąsior, G. Zając, M. Szczelina, Wrocław [b.d.w.].

\begin{abstract}
Abstrakt
Infrastruktura portu lotniczego jest i pozostanie atrakcyjnym celem ataków terrorystycznych. Wszelkie zmiany i innowacje w jej obrębie powinny mieć na celu niedopuszczenie do kolejnych zamachów terrorystycznych. Należy zdawać sobie sprawę, że nie istnieje system, który zapewniłby 100-procentowe zabezpieczenie przed zagrożeniami terrorystycznymi. Dowodem na powyższą tezę może być chociażby zamach na brukselskim lotnisku Zaventem.
\end{abstract}

\title{
Changes in Security Systems at Airports In the Context of Terrorist Threats
}

\begin{abstract}
The airport infrastructure has always been the target of terrorist attacks. Any changes and innovations within it should be aimed at preventing such attacks. Full security cannot be guaranteed by any system, which may be proved by the terrorist attempt at the airport of Zaventem near Brussels.
\end{abstract}

